\title{
Compositional and Functional Considerations for Bovine-, Caprine- and Plant-Based Infant Formulas
}

\author{
Margaret E. Byrne, James A. O'Mahony (D) and Tom F. O'Callaghan *(D) \\ School of Food \& Nutritional Sciences, University College Cork, T12 YT20 Cork, Ireland; \\ margaretbyrne@umail.ucc.ie (M.E.B.); sa.omahony@ucc.ie (J.A.O.) \\ * Correspondence: tom_ocallaghan@ucc.ie; Tel.: +353-(0)21-4902762
}

Citation: Byrne, M.E.; O’Mahony, J.A.; O'Callaghan, T.F. Compositional and Functional Considerations for Bovine-, Caprine- and Plant-Based Infant Formulas. Dairy 2021, 2, 695-715. https://doi.org/10.3390/ dairy2040054

Academic Editor:

Kasper Arthur Hettinga

Received: 17 September 2021

Accepted: 8 November 2021

Published: 6 December 2021

Publisher's Note: MDPI stays neutral with regard to jurisdictional claims in published maps and institutional affiliations.

Copyright: (c) 2021 by the authors. Licensee MDPI, Basel, Switzerland. This article is an open access article distributed under the terms and conditions of the Creative Commons Attribution (CC BY) license (https:// creativecommons.org/licenses/by/ $4.0 /)$.

\begin{abstract}
Breastmilk is the optimal source of nutrition for infants. However, in circumstances where breastfeeding is not possible or feasible, infant formula provides an essential alternative to fulfil the nutritional requirements of the developing infant. Traditionally, the manufacture of infant formula has involved utilisation of bovine milk as a base ingredient, formulated with other nutrients and bioactive ingredients to closely match the composition of human breastmilk. While it is the most widely available type of formula on the market, bovine-based infant formula is not suitable for all infants, and therefore alternatives such as those based on caprine milk, soy and rice protein are becoming increasingly available. This review provides a detailed examination of the composition of infant formula prepared from bovine milk, caprine milk, soy, and rice protein sources. Available literature on nutrient bio-accessibility and aspects of protein functionality relevant to infant formula is discussed.
\end{abstract}

Keywords: infant formula; bovine milk; caprine milk; soy; rice; composition; digestibility; functionality; metabolomics

\section{Introduction}

Breastmilk is widely regarded as the optimum source of nutrition for infants. The composition of breastmilk is individual specific and evolves throughout lactation to fulfil the nutritional needs of the growing infant [1]. In addition, clinical studies have demonstrated that breastfeeding is linked with decreased risk of infant mortality, infectious morbidity, and dental malocclusions [2]. Breastfeeding has also been reported to have a long-term protective effect against type II diabetes mellitus and obesity [1-3]. From a maternal perspective, benefits of breastfeeding include improved spacing between pregnancies and decreased risk of breast and ovarian cancers [2,3].

The World Health Organisation (WHO) recommends exclusive breastfeeding for the first six months of life, followed by the introduction of appropriate complementary foods after six months with continued breastfeeding until at least 2 years of age [4]. Breastfeeding is further endorsed by a range of national health organisations and expert bodies, including the European Society for Paediatric Gastroenterology, Hepatology and Nutrition (ESPGHAN), the Scientific Advisory Committee on Nutrition (SACN), and the American Academy of Paediatrics [1,3,5]. However, for several reasons, many women cannot, or choose not to breastfeed exclusively for the recommended duration. In Ireland for example, breastmilk typically provides the first feed following birth in only $68.3 \%$ of babies born in 2019 [6], and by hospital discharge, the rate of breastfeeding decreases sharply, with only $37.3 \%$ of babies being exclusively breastfed [6]. In circumstances when an infant is not exclusively breastfed, infant formula provides an alternative feed source to meet the infant's nutritional needs.

According to European Union (EU) legislation, infant formula may be defined as "food intended for use by infants during the first months of life and, satisfying by itself, 
the nutritional requirements of such infants until the introduction of appropriate complementary feeding" [7]. Bovine milk is the primary base material from which infant formula is manufactured today, due to its well-established distribution chains, high production volumes, and the recognised functional properties of its components [8]. However, parents may choose to feed their infant with an alternative non-dairy-based infant formula for a variety of reasons. For example, cow's milk protein allergy (CMPA) is recognised as one of the most frequent sources of food-related allergy in children [9,10]. It is caused by an immunoglobulin (Ig)E-mediated, non-IgE-mediated, or mixed immune reaction to cow's milk protein, resulting in a range of symptoms involving a variety of organ systems, including the skin, digestive system, and respiratory system [10]. Strict avoidance of formula containing cow's milk proteins, unless extensively hydrolysed, is necessary for the management of this condition [10]. Further reasons for use of bovine alternative formulas may include disorders of carbohydrate metabolism, such as primary lactase deficiency or galactosemia, and religious, cultural, or ethical reasons such as environmental or animal welfare considerations, resulting in the desire to adopt a vegan lifestyle [11-13]. In some instances, caprine milk-based infant formula or formulas from plant sources provide important alternatives to bovine-based infant formula. This review examines the available literature on infant formulas from bovine, caprine, and plant sources, examining their composition, functional and digestive considerations.

\section{Proteins in Infant Formula}

The composition of infant formula is strictly regulated following guidelines set by governing bodies such as the EU in Europe, the Food and Drug Administration (FDA) in the United States of America and the Codex Alimentarius commission internationally [14-16]. Under current EU legislation, sources of protein permissible in infant formulas are bovine milk protein, caprine milk protein, soy protein isolates, and hydrolysed proteins [14]. Formulas based on hydrolysed rice proteins are also commercially available and are sold as a "food for special medical purpose" (FSMP), targeted at infants suffering from CMPA [17]. The protein contents of bovine and caprine milk are approximately $30-35 \mathrm{~g} / \mathrm{L}$ total protein; however, the composition of both bovine and caprine milk is variable, dependent on many factors including the breed, diet, stage of lactation, and health status of the animal [18-20]. Proteins in milk can be separated into two main fractions: casein and whey. Both bovine and caprine milk are casein dominant, with a whey to casein ratio of approximately 20:80 [18,19]. The protein profile of mature bovine and caprine milk are shown in Table 1.

Table 1. Concentration (g/L) of individual proteins in mature bovine, caprine and human milk. Reprinted with permission from Ref. [20]. Copyright 2014 Elsevier.

\begin{tabular}{cccc}
\hline & Bovine Milk & Caprine Milk & Human Milk \\
\hline Total casein & $24.6-28.0$ & $23.4-46.3$ & $2.4-4.2$ \\
$\alpha_{\text {S1-casein }}$ & $8.0-10.7$ & $0-13.0$ & 0.77 \\
$\alpha_{\text {S2-casein }}$ & $2.8-3.4$ & $2.4-11.6$ & - \\
$\beta$-casein & $8.6-9.3$ & $0-29.6$ & 3.87 \\
K-casein & $2.3-3.3$ & $2.8-13.4$ & 0.14 \\
Total whey & $5.5-7.0$ & $3.7-7.0$ & $6.2-8.3$ \\
$\beta$-lactoglobulin & $3.2-3.3$ & $1.5-5.0$ & - \\
$\alpha$-lactalbumin & $1.2-1.3$ & $0.7-2.3$ & $1.9-3.4$ \\
Serum albumin & $0.3-0.4$ & - & $0.4-0.5$ \\
Immunoglobulins (Ig) & $0.5-1.0$ & - & $0.96-1.3$ \\
IgG & $0.15-0.8$ & $0.1-0.4$ & 0.03 \\
IgA & $0.05-0.14$ & $0.03-0.08$ & 0.96 \\
IgM & $0.04-0.1$ & $0.01-0.04$ & 0.02 \\
Lactoferrin & $0.02-0.5$ & $0.02-0.2$ & \\
\hline
\end{tabular}

Caseins are phosphoproteins, synthesised in the mammary gland and are unique to milk. They are defined by their precipitation from solution when the $\mathrm{pH}$ of milk is adjusted to $\mathrm{pH}$ 4.6. Bovine and caprine casein consists of four gene products: $\alpha_{\mathrm{s} 1^{-}}, \alpha_{\mathrm{s} 2^{-}}, \beta$ - and 
$\mathrm{k}$-casein. In bovine milk, $\alpha_{\mathrm{s} 1}$-casein is the dominant casein fraction, while $\beta$-casein is the primary casein in caprine milk [21]. As can be seen in Table 1, there is a large variation in the relative proportions of the caseins in caprine milk, which is due to genetic variability on the casein loci of goats [21,22]. Of particular interest are the polymorphisms of $\alpha_{\mathrm{s} 1}$-casein, which result in four different levels of expression, ranging from $3.5 \mathrm{~g} / \mathrm{L}$ per copy of the strong alleles, $\mathrm{A}, \mathrm{B}$, or $\mathrm{C}$, to $0 \mathrm{~g} / \mathrm{L}$ per copy of the null allele, referred to as $\mathrm{O}[21,22]$. The allele frequencies at the $\alpha_{s 1}$-casein locus vary with breed. For example, alleles $\mathrm{E}$ and $\mathrm{F}$, which are associated with medium $(1.1 \mathrm{~g} / \mathrm{L}$ per allele) and low contents $(0.5 \mathrm{~g} / \mathrm{L}$ per allele $)$ of $\alpha_{\mathrm{s} 1}$-casein, respectively, are predominant in French and Italian Alpine and Saanen goats. Polymorphisms associated with different levels of synthesis have also been identified for $\alpha_{\mathrm{s} 2^{-}}, \beta$ - and $\mathrm{k}$-casein [22].

Caseins in milk associate together in the presence of calcium ions $\left(\mathrm{Ca}^{2+}\right)$ to form colloidally stable particles known as micelles [19]. The casein micelles in bovine milk are smaller than that of caprine milk at 150-182 nm compared to $260 \mathrm{~nm}$, respectively [20]. The larger casein micelles in goat milk are related to the lower levels of $\alpha_{\mathrm{s} 1}$-casein in this species and these differences in size are thought to have implications for the digestibility of casein $[18,23]$.

Whey protein is the protein fraction that remains soluble when the $\mathrm{pH}$ of milk is adjusted to 4.6, i.e., the serum proteins [19]. The main whey proteins in bovine and caprine milk are $\beta$-lactoglobulin, $\alpha$-lactalbumin, immunoglobulins, and serum albumin, the typical quantities of which are shown in Table $1[19,20]$. Whey proteins also consist of trace amounts of a variety of other proteins, including lactoferrin and enzymes [19].

The composition of infant formula is traditionally derived from that of human milk [24]. The protein content of human milk is approximately 3-fold lower than that of bovine or caprine milk at 9-11 g/L [24,25]. Furthermore, human milk is whey dominant with a whey to casein ratio of $\sim 60: 40$ [24,25]. Bovine and caprine milk-based infant formulas are formulated to contain approximately $1.3-1.5 \mathrm{~g} / 100 \mathrm{~mL}$ of protein, remaining higher than human milk to compensate for lower levels of essential amino acids in the milk from these animals [24,25]. For bovine milk-based infant formula, this is usually achieved by combining skim milk, demineralised whey, whey protein concentrate (WPC), or whey protein isolate (WPI) at the required quantities, which also creates a whey to casein ratio comparable to that of human milk $[8,24]$. However, in the manufacture of caprine milk-based infant formula, whole milk is commonly used as a base to obtain the required concentration of protein, and therefore the natural whey to casein ratio of 20:80 is retained $[18,26]$.

Unlike bovine and caprine milk, plant-based proteins such as soybean and rice do not contain casein or whey. Soy-based infant formula was first introduced in the United States in the early 1900s with the original purpose of providing an alternative to cow's milk protein-based formula for infants displaying signs of intolerance [12,13]. Soybean seeds contain $40-41 \%$ protein (dry weight) [27,28], with storage proteins making up $65-80 \%$ of total protein. The two major storage proteins are glycinin and $\beta$-conglycinin, which are part of the 11S and 7S globulin families, respectively $[27,28]$. Glycinin and $\beta$-conglycinin make up 40 and $25 \%$ of the seed protein, respectively; however, this varies depending on factors such as the genetic background of the soybean, the growing environment, and maturity of the plant at harvest $[27,28]$. Glycinin is a hexamer that consists of two trimers linked by electrostatic, ionic, hydrogen, and hydrophobic bonds [27,28]. Each trimer has three monomeric subunits, and each monomeric subunit consists of an acidic and a basic polypeptide, linked by disulphide bonds $[27,28]$. $\beta$-conglycinin consists of three subunits: $\alpha, \alpha^{\prime}$ and $\beta$; which associate through hydrogen and hydrophobic bonds $[27,28]$.

Originally, soy flour, with a protein content of approximately $54 \%$, was used as a protein source in development of soy-based infant formula [29,30]. However, this was replaced in the 1960s by soy protein isolates (SPIs), due to the high levels of fibres, trypsin inhibitors, and phytate present in soy flour, collectively inhibiting digestibility [30]. SPIs are obtained from defatted oil flake by solubilising at a weak alkaline $\mathrm{pH}$, followed by 
precipitation at the isoelectric point of $\sim 4.5$; the resulting material has a protein content of $\geq 90 \%[29,30]$.

Hydrolysed rice-based infant formulas were first introduced in Europe in the early 2000s [17]. Rice proteins are hypoallergenic and therefore are suited to infants with CMPA $[17,31,32]$. Rice grain milling fractions have varied protein contents; brown rice grains have a protein content of approximately $7.1-8.3 \%$, while milled rice has a lower protein content of $6.3-7.1 \%$ due to the removal of the bran layer, which contains approximately $11.3-14.9 \%$ protein [33]. There are four categories of rice protein, separated based on their solubility: glutelin (alkali/acid-soluble), albumin (water-soluble), globulin (salt-soluble), and prolamin (alcohol-soluble) [32,33]. Glutelin is the dominant protein fraction, and it is extensively aggregated and crosslinked via disulphide bonds, resulting in high insolubility in water which limits the functionality of intact rice proteins [31-33]. Rice protein, as used in infant formula is typically extensively hydrolysed, to improve its solubility and other important functional properties (e.g., emulsification) in this application [17,32]. Extraction of protein from rice bran is challenging due to the presence of high amounts of fat, which acts as a substrate for enzyme activity, resulting in the development of off-flavours and rancidity $[17,32]$ and also the high proportions of insoluble carbohydrate (e.g., fibre) components. Therefore, rice bran must be defatted or stabilised by heat treatments which have the potential to denature the proteins [17,32]. Rice endosperm protein is more easily extracted, which is achieved by alkaline or enzymatic extraction $[17,32]$.

Soy- and rice-based infant formulas both have higher concentrations of protein than bovine or caprine milk-based infant formulas. Soy-based infant formulas typically have protein contents of $1.65-1.9 \mathrm{~g} / 100 \mathrm{~mL}$, while commercially available hydrolysed rice-based infant formulas contain $1.7-2.1 \mathrm{~g} / 100 \mathrm{~mL}$ protein $[12,17]$, due largely to the potentially lower digestibility and bioavailability of these protein sources compared to bovine and caprine milk protein [13].

\section{Protein Quality and Amino Acid Requirements in Infant Formula}

Protein quality may be defined by the ability of a protein to satisfy metabolic requirements for nitrogen and amino acids, as determined by the amino acid content of the protein, protein digestibility, and the bioavailability of each amino acid [34]. Protein quality is commonly assessed using protein-digestibility corrected amino acid scores (PDCAAS), a method which was originally proposed by the Food and Agriculture Organisation/World Health Organisation (FAO/WHO) in 1989 [34,35]. However, the PDCAAS method has a number of significant limitations; for example, PDCAAS values are calculated based on faecal digestibility of crude protein; however, it is known that not every amino acid has the same digestibility as crude protein and that amino acid digestibility is more accurately determined at the ileum $[35,36]$. It has also been reported that PDCAAS generally underestimates the value of high-quality proteins and overestimates the value of low-quality proteins [36]. As a result of these limitations, the FAO has recommended the replacement of PDCAAS with digestible indispensable amino acid scores (DIAAS), which are calculated as follows [35]:

$$
\text { DIAAS }(\%)=100 \times\left(\begin{array}{c}
\begin{array}{c}
\mathrm{mg} \text { of digestible dietary indispensible amino acid } \\
\text { in } 1 \mathrm{~g} \text { of the dietary protein }
\end{array} \\
\begin{array}{c}
\mathrm{mg} \text { of the same dietary indispensible amino acid } \\
\text { in } 1 \mathrm{~g} \text { of reference protein }
\end{array}
\end{array}\right)
$$

Using the DIAAS method, digestibility should be based on true ileal digestibility of each amino acid, preferably in humans, but also pig or rat models (in that order) if data from humans are not available [35]. The recommended amino acid scoring patterns are provided in Table 2. The amino acid composition of human milk provides the reference amino acid scoring pattern for infants [35]. 
Table 2. Recommended amino acid scoring patterns for infants, children and older children, adolescents, and adults (mg/g protein requirement) [35].

\begin{tabular}{|c|c|c|c|c|c|c|c|c|c|}
\hline Age Group & His $^{1}$ & Ile $^{2}$ & Leu $^{3}$ & Lys 4 & SAA $^{5}$ & AAA $^{6}$ & Thr $^{7}$ & $\operatorname{Trp}^{8}$ & Val $^{9}$ \\
\hline Infants (0-6 months) & 21 & 55 & 96 & 60 & 33 & 94 & 44 & 17 & 55 \\
\hline Child ( 6 months -3 years) & 20 & 32 & 66 & 57 & 27 & 52 & 31 & 8.5 & 43 \\
\hline Older child, adolescent, adult & 16 & 30 & 61 & 48 & 23 & 41 & 25 & 6.6 & 40 \\
\hline
\end{tabular}

${ }^{1}$ Histidine; ${ }^{2}$ isoleucine; ${ }^{3}$ leucine; ${ }^{4}$ lysine; ${ }^{5}$ sulphur amino acids (methionine and cysteine); ${ }^{6}$ aromatic amino acids (phenylalanine and tyrosine); ${ }^{7}$ threonine; ${ }^{8}$ tryptophan; ${ }^{9}$ valine.

Available data on DIAAS of protein sources used in infant formula, calculated using infant amino acid scoring patterns as shown in Table 2, are limited. One such example is a study by Mathai et al. [36], who reported DIAAS values for WPC, WPI, milk protein concentrate (MPC), skimmed milk protein (SMP), and SPI determined in pigs. The DIAAS values obtained were $71,67,85,81$, and 68 for WPC, WPI, MPC, SMP and SPI, respectively [36]. However, a limitation of this study was that the proteins were fed as raw ingredients, and therefore the digestibility recorded from such a study may not be reflective of these as present in infant formula, in which proteins undergo substantial processing and heat treatments during manufacturing, which may modify their digestibility [36].

To overcome ethical issues associated with conducting in vivo digestibility studies, Maathuis et al. [37] used an in vitro digestion model to determine the DIAAS of human milk protein, and bovine and caprine milk protein as present in commercially available infant formulas. The DIAAS for the caprine milk-based formula, bovine milk-based formula, and human milk as determined for infants $<6$ months old was 83,75 , and $77 \%$, respectively, therefore demonstrating that the protein quality of caprine and bovine milk-based infant formulas is comparable to human milk under simulated infant digestive conditions [37]. However, comparison with other studies is not possible due to a lack of available literature and data, in this area.

In addition to achieving protein requirements, the protein sources in infant formula must also provide the required levels of indispensable and conditionally indispensable amino acids set out in the legislation, as outlined in Table 3.

Table 3. Indispensable and conditionally indispensable amino acids in breast milk (mg) [14].

\begin{tabular}{ccc}
\hline & Per $\mathbf{1 0 0} \mathbf{~ k J}$ & Per 100 kcal \\
\hline Indispensable amino acids & & \\
Histidine & 10 & 40 \\
Isoleucine & 22 & 90 \\
Leucine & 40 & 166 \\
Lysine & 27 & 113 \\
Methionine & 5 & 23 \\
Phenylalanine & 20 & 83 \\
Threonine & 18 & 77 \\
Tryptophan & 8 & 32 \\
Valine & 21 & 88 \\
Cysteine & 9 & 38 \\
Tyrosine & 18 & 76 \\
\hline
\end{tabular}

In circumstances whereby the source of protein does not contain the indispensable amino acids listed in Table 3 in sufficient quantities, they may be supplemented as free amino acids in appropriate amounts [14]. For example, rice protein ingredients contain limited amounts of lysine, threonine, and tryptophan, and therefore rice-based infant formulas are often supplemented with these amino acids [17]. Similarly, the quality of soy protein is limited by the content of its sulphur-containing amino acids, and so methionine is often added to soy-based infant formula $[13,36]$. Caprine milk has lower concentrations of cysteine, tryptophan, and isoleucine per gram of protein compared to human milk, and 
these are supplemented in caprine milk-based infant formula where whole goat milk is used as the protein source [26]. In the case where attempts have been made to reduce the protein content of bovine milk-based infant formula to more closely match the protein content of human milk, tryptophan and cysteine become the first limiting amino acids, and studies in the past have reported low plasma tryptophan levels in formula-fed infants [38]. While the fortification of infant formula with free amino acids has been shown to raise plasma levels of these amino acids in infants, these will likely be absorbed and reach target tissues more quickly than protein-bound amino acids, which require proteolysis and release from the respective proteins before absorption, with little known regarding the metabolic consequences of this [38,39].

An alternative approach to achieving a more desirable amino acid profile in bovine milk-based infant formula is through alteration of the composition of the whey protein fraction. While $\beta$-lactoglobulin is the dominant whey protein in bovine and caprine milk, it is absent in human milk and instead, $\alpha$-lactalbumin is the major whey protein, representing up $20-25 \%$ of total protein [40]. $\alpha$-lactalbumin is rich in essential amino acids, including tryptophan and cysteine, and therefore altering the $\alpha$-lactalbumin to $\beta$-lactoglobulin ratio of whey in the manufacture of bovine milk-based infant formula enables closer matching of the amino acid profile to that of human milk $[38,40,41]$. Davis et al. [41] performed a large, multicentre, randomised control trial (RCT) $(n=216)$ investigating the effects of an $\alpha$-lactalbumin-enriched infant formula on healthy, term infants. The experimental formula (EF) had a lower protein content, but higher $\alpha$-lactalbumin content than the standard formula (SF) (1.4 g/100 mL vs. $1.5 \mathrm{~g} / 100 \mathrm{~mL}$ protein; $2.2 \mathrm{~g} / 100 \mathrm{~mL}$ vs. $1.3 \mathrm{~g} / 100 \mathrm{~mL}$, respectively) and the indispensable amino acid composition of the EF was closer to human milk than the SF for six amino acids [41]. After 8 weeks, all mean plasma indispensable amino acid levels in the EF were as high as those in the SF and human milk groups [41].

\section{Carbohydrates in Infant Formula}

Carbohydrates can be grouped into two broad categories: glycaemic carbohydrates and non-glycaemic carbohydrates [42]. Glycaemic carbohydrates are those which are digested and absorbed in the small intestine followed by an increase in blood glucose, while non-glycaemic carbohydrates pass through undigested to the large intestine without raising blood glucose, and therefore may exert prebiotic effects [42]. EU legislation regarding the composition of infant formula specifies a minimum total carbohydrate content of $9 \mathrm{~g} / 100 \mathrm{kcal}[14]$.

\subsection{Glycaemic Carbohydrates}

Glycaemic carbohydrates act as an essential energy source for the infant, with diets lacking in carbohydrates leading to hypoglycaemia [25]. In the case of caprine and bovine milk-based infant formula, lactose acts as the primary source of carbohydrate, containing approximately $7-7.5 \mathrm{~g} / 100 \mathrm{~mL}$ of lactose, based on the content of lactose in human milk $(\sim 7 \%)$. Lactose is the main carbohydrate in bovine and caprine milk, containing $44-56 \mathrm{~g} / \mathrm{L}$ and $32-50 \mathrm{~g} / \mathrm{L}$, respectively [20]. Pure lactose is widely available as an ingredient from the processing of bovine milk and whey, and therefore it is relatively straightforward to fortify such formulations with lactose to match human milk levels.

Carbohydrates naturally present in soybeans and rice grains are largely separated from their protein fractions during the protein extraction steps in the processing of these raw materials [29,32]. Maltodextrins are commonly used as the primary carbohydrate source in infant formulas based on soy and rice protein, generally consisting of dried starch hydrolysis products with dextrose equivalent (DE) of $\leq 20$ [43]. Their use in soy and hydrolysed rice-based infant formulas, and the absence of lactose in these plant protein sources enables the use of these formulas in infants with hereditary lactase deficiency or galactosemia, where strict lactose elimination is required $[12,13,17]$. Glucose syrup/dried glucose syrup may also be used as a substitute for lactose in lactose-free formulas, permitted only with $\mathrm{DE} \leq 32$, and the glucose content resulting from its use should not 
exceed $0.84 \mathrm{~g} / 100 \mathrm{kcal}$ [14]. Lactose-free infant formulas based on bovine milk protein, where lactose has been removed by enzymatic hydrolysis or membrane filtration are also available [25].

Pre-cooked or gelatinised starches may be added to infant formula to a maximum of $30 \%$ of the total carbohydrate content [14]. This increases the viscosity of formulas targeted at infants suffering from gastrointestinal reflux [44]. They are also commonly added to hydrolysed infant formulas, as protein hydrolysis increases the osmolarity of the formula which may encourage regurgitation as a result of delayed gastric emptying and cause softer and more frequent stools due to increased intraluminal water secretion [17]. Other carbohydrate sources permitted for use in infant formula include maltose, sucrose, and glucose. Glucose and sucrose are only permitted in infant formulas manufactured from protein hydrolysates and may be useful for improving the palatability of these formulas, which can be bitter $[8,14,42]$.

\subsection{Non-Glycaemic Carbohydrates}

Oligosaccharides represent a significant component of human milk, with concentrations in the range 5-10 g/L [20]. Human milk oligosaccharides (HMOs) resist digestion in the upper gastrointestinal tract (GIT) and are thought to exert prebiotic effects by serving as a substrate for beneficial bacteria such as bifidobacteria [45,46]. They are also thought to be antimicrobial, possessing the ability to act as decoys to prevent the binding of pathogenic bacteria and toxins to target oligosaccharides on epithelial cell surfaces [45,46]. Bovine milk has a much lower oligosaccharide content than human milk, containing only $0.03-0.09 \mathrm{~g} / \mathrm{L}$ [20]. In addition, HMOs have a much greater structural diversity than the oligosaccharides present in bovine milk [45]. The oligosaccharide concentration of caprine milk is almost 10-fold greater than that of bovine milk at $0.25-0.3 \mathrm{~g} / \mathrm{L}$, and while this is still much lower than the concentration of oligosaccharides in human milk, the oligosaccharides in caprine milk are more structurally similar to HMOs [20,45].

Due to the observed beneficial effects of HMOs in breastfed infants, much work has been carried out on developing HMO-like fractions for addition to infant formulas. For example, structurally identical forms of two HMOs, $2^{\prime}$-Fucosyllactose $\left(2^{\prime} \mathrm{FL}\right)$ and Lacto$\mathrm{N}$-neotetrose (LNnT) have been developed and are produced in commercial volumes by microbial fermentation [47]. In recent years, their safety for use in infants has been approved by the Food and Drug Administration (FDA) in the US and the European Commission in Europe, and they are now incorporated into various infant formulas [47]. Alternatively, infant formula manufacturers have added non-digestible carbohydrates such as fructooligosaccharides (FOS) and galactooligosaccharides (GOS) to infant formula to replicate some of the beneficial effects of HMOs [46]. FOS and GOS are not naturally present in human milk and unlike HMOs, they are not sialylated or fucosylated [46]. However, despite their structural differences, their ingestion in infant formula has, like HMOs, been shown to exhibit prebiotic effects [46].

\section{Lipids in Infant Formula}

Lipids are the primary energy source in infant formula, providing $40-50 \%$ of the infant's energy requirements [25]. According to current EU legislation, the lipid content of infant formulas must be between 4.4 and $6.0 \mathrm{~g} / 100 \mathrm{kcal}$ [14]. Minimum requirements are also set for the essential fatty acids, linoleic acid (LA) (C18:2w6) and $\alpha$-linolenic acid (ALA) (C18:3w3), which the infant is unable to synthesise, and therefore must be provided by the diet [14]. Bovine and caprine milk lipids are not suitable as the sole source of lipids in infant formula due to large differences in their fatty acid profiles compared to human milk, which has a lower level of short-chain fatty acids (SCFAs) (C:4-C:8), and a higher proportion of unsaturated (C18:1, C18:2, and C18:3) and long-chain polyunsaturated fatty acids (LCPUFAs) (C20:4 and C22:6) than bovine and caprine milk [20,25]. These differences in fatty acid profile are largely due to differences in mechanisms of fatty acid synthesis between these species. While the fatty acid profile of human milk reflects dietary fatty acid 
intake, polyunsaturated fatty acids (PUFAs) ingested by cows and goats are hydrogenated by ruminant bacteria forming saturated fatty acids before absorption, thereby limiting the amount of PUFAs present in their milk [19,20,48].

As a result of these differences, vegetable oils such as palm, soybean, coconut, sunflower, and high-oleic safflower are used as the primary lipid source in infant formulas made from bovine and caprine milk, blended in a combination that provides a similar fatty acid profile to that of human milk $[25,48]$. Vegetable oil blends are also the primary source of lipids in soy- and rice-based infant formulas [12,17]. Blends of these oils, however, are lacking in the LCPUFAs, arachidonic acid (ARA) (C20:4w6), and docosahexaenoic acid (DHA) (C22:6w3). It was previously presumed that infants could synthesise sufficient amounts of these LCPUFAs from their precursors LA and ALA [25]. However, the presence of these LCPUFAs in human milk, combined with reports of improved cognitive function in breastfed infants compared to formula-fed infants has suggested that their supplementation in infant formula may be important for optimal development [49]. EU legislation currently indicates that infant formulas must contain $20-50 \mathrm{mg} / 100 \mathrm{kcal}$ DHA [14]. LCPUFAs may be added to infant formula in the form of fish oils, single-cell microalgal and fungal oils and egg-yolk-derived lipids; however, the use of unfractionated fish oil is unsuitable due to the presence of eicosapentaenoic acid (EPA), which is antagonistic to the functions of ARA [24,25].

In addition to the types of fatty acids that are present in infant formula, triglyceride structure is also of importance as it affects lipid digestion, and therefore the bioavailability of fatty acids. Triglyceride synthesis involves specific esterification of fatty acids to glycerol on the outer sn-1 and sn-3, and inner sn-2 positions of the triglyceride [50]. In human milk, $>70 \%$ of palmitic acid (C16:0) is located at the sn-2 position on the triglyceride backbone $[50,51]$. However, in vegetable oils, palmitic acid is almost entirely positioned at either the sn-1 or sn-3 positions [50]. Endogenous lipases preferentially hydrolyse fatty acids from the sn- 1 and sn- 3 positions on the triglyceride, releasing two unesterified fatty acids and one sn-2 monoglyceride into the intestinal lumen [50]. Unesterified palmitic acid is poorly absorbed and can form complexes with divalent cations like calcium, forming insoluble soaps, leading to malabsorption of calcium and harder stools in infants fed formulas with high proportions of these vegetable oils [50,51]. For this reason, structured triglycerides have been developed through enzymatic processes, which contain 17-25\% palmitic acid, with over $40 \%$ of this palmitic acid esterified at the sn-2 position [50,51]. Incorporation of these structured triglycerides in infant formula has been associated with improved bone development, decreased intestinal inflammation, modified intestinal microflora, and reduced instance of colic [50].

Infant formulas typically undergo a homogenisation step during their manufacture. This results in the formation of submicronic vegetable oil globules $(\sim 0.4-0.5 \mu \mathrm{m})$, stabilised by a layer of protein [51]. In bovine and caprine milk-based infant formulas, the stabilising proteins are casein and whey proteins; while in soy- and rice-based formulas, soy proteins and hydrolysed rice proteins are the primary emulsifiers of fat globules in these formulas, respectively [52]. Additional emulsifiers, such as soy lecithin and citric acid esters of mono-/di-glycerides (CITREM) may also be added to assist the innate protein-based emulsifiers with emulsion stability $[25,52]$. In contrast, milk fat globules in bovine, caprine, and human milk are much larger, with mean diameter of 3-5 $\mu \mathrm{m}$, and are stabilised by a tri-layer membrane, the milk fat globule membrane (MFGM) [51,53-55]. The size of the lipid globules and composition of the lipid/water interface have been demonstrated to affect the digestion properties of infant formulas [56]. As a result, there have been attempts to modify the composition of the lipid/water interface, for example, by modifying the phospholipid content of bovine milk-based infant formula via the addition of bovine milk phospholipids [24,57]. As mentioned, whole goat milk is commonly used as the raw material to provide the required protein content of caprine milk-based infant formulas. Prosser et al. [58] investigated the fatty acid composition of a caprine milk-based infant formula in which $55 \%$ of the total fat was provided by goat milk fat and the remainder with 
a vegetable oil blend, reporting that this blend achieved the fatty acid profile recommended for infants [58]. It contained $17 \%$ palmitic acid, of which $31 \%$ was esterified at the sn2 position, thereby providing a natural source of sn-2 palmitate [58]. Infant formulas containing whole goat milk also retain some MFGM components which have been linked with immune, metabolic, and cognitive development in infants [53]. However, further investigation is required to fully determine the effects of these MFGM components as present in caprine milk-based infant formula [53].

\section{Micronutrients and Infant Formula}

\subsection{Minerals}

Bovine and caprine milk have much higher mineral contents than human milk, with ash contents of 7-8, 7-9, and $2-3 \mathrm{~g} / \mathrm{L}$, respectively $[8,20,25]$. The high levels of electrolytes $(\mathrm{Na}, \mathrm{K}, \mathrm{Cl}$, and $\mathrm{P})$, combined with the high protein concentration in unmodified bovine and caprine milk results in potential for high renal solute load for infants, which leads to an increased risk of developing hypertonic dehydration [8,25]. Modifications made to these milks to lower their protein content also reduce their ash content to more suitable levels for infant feeding. Amagliani et al. [59] reported ash contents of $6.17 \pm 0.07 \% w / w$ and $10.0 \pm 0.04 \% w / w$ for two rice endosperm hydrolysate ingredients, while the ash content of SPI is reported to be approximately $4.5 \%$ on a dry basis [29,59].

The mineral requirements for infant formulas as per EU legislation are given in Table 4.

Table 4. Mineral requirements for infant formula manufactured from bovine milk protein, caprine milk protein or protein hydrolysates [14].

\begin{tabular}{ccccc}
\hline & \multicolumn{2}{c}{ Per 100 kJ } & \multicolumn{2}{c}{ Per 100 kcal } \\
\hline & Minimum & Maximum & Minimum & Maximum \\
Sodium $(\mathrm{mg})$ & 6 & 14.3 & 25 & 60 \\
Potassium $(\mathrm{mg})$ & 19.1 & 38.2 & 80 & 160 \\
Chloride $(\mathrm{mg})$ & 14.3 & 38.2 & 60 & 160 \\
Calcium $(\mathrm{mg})$ & 12 & 33.5 & 50 & 140 \\
Phosphorus $(\mathrm{mg})$ & 6 & 21.5 & 25 & 90 \\
Magnesium $(\mathrm{mg})$ & 1.2 & 3.6 & 5 & 15 \\
Iron $(\mathrm{mg})$ & 0.07 & 0.31 & 0.3 & 1.3 \\
Zinc $(\mathrm{mg})$ & 0.12 & 0.24 & 0.5 & 1 \\
Copper $(\mu \mathrm{g})$ & 14.3 & 24 & 60 & 100 \\
Iodine $(\mu \mathrm{g})$ & 3.6 & 6.9 & 15 & 49 \\
Selenium $(\mu \mathrm{g})$ & 0.72 & 2 & 3 & 8.6 \\
Manganese $(\mu \mathrm{g})$ & 0.24 & 24 & 1 & 14 \\
Molybdenum $(\mu \mathrm{g})$ & - & 3.3 & - & 100 \\
Fluoride $(\mu \mathrm{g})$ & - & 24 & - &
\end{tabular}

In situations where the innate levels of minerals obtained from the protein and carbohydrate sources are insufficient to meet the required levels in Table 4, fortification of the infant formula with mineral salts is required. However, it is preferable to maximise the amounts of innate minerals, as fortification with mineral salts can promote instability of the infant formula $[8,25]$. For example, the heat stability of bovine milk is reduced by the addition of soluble calcium salts as demonstrated by Omoarukhe et al. [60], who reported that increasing the calcium concentration of milk by $30 \mathrm{mM}$ with soluble calcium salts (calcium lactate, calcium chloride, and calcium gluconate) led to decreased $\mathrm{pH}$ and increased ionic calcium, which in turn decreased the heat stability of the milk, resulting in an undesirable firm coagulum when in-container sterilisation treatments were applied. Milk samples in which insoluble calcium salts (calcium carbonate, calcium phosphate, and calcium citrate) were added remained stable under these conditions but sediment was formed [60]. Calcium supplementation has also been shown to influence the thermal stability of SPI stabilised emulsions. Ryan et al. [61] observed that calcium supplementation to 450 and $850 \mathrm{mg} / \mathrm{L}$, spanning the concentration range relevant to infant formulas, significantly reduced the heat coagulation time (HCT) of SPI model emulsions $(p \leq 0.05)$, 
with a lesser effect on HCT found on supplementation with calcium citrate compared to calcium chloride. Caprine casein micelles are more highly mineralised than those of bovine casein $[8,23]$, and as a result, goat milk is also high in free calcium ions due to insufficient levels of citrate for complexation, leading to reduced heat stability $[8,23]$. Therefore, the addition of citrate or phosphate salts may be necessary to enhance the heat stability of caprine milk-based infant formula [8].

Phytic acid (myo-inositol hexaphosphoric acid) is an antinutrient compound present in both soy and rice which can chelate nutritionally essential minerals such as zinc, iron, calcium, and magnesium, thereby reducing their bioavailability [27,62]. Phytic acid is distributed evenly throughout the kernel of oilseeds such as soy, and SPI is reported to contain $1-2 \%$ phytic acid $[13,62]$. Phytic acid primarily accumulates within the aleurone layer of rice, which is removed during milling forming part of the rice bran, and therefore its concentration is likely to be low if hydrolysed rice endosperm protein is used as the protein source in rice-based infant formula [32,62]. However, there is a lack of data available on the concentration of phytic acid in rice proteins used in infant formulas and how they may affect the bioavailability of nutrients in such formulas.

The phytic acid concentration of soy formulas may be reduced by precipitation methods or by treatment with phytase enzymes, which has previously been shown to significantly increase absorption of zinc [13,62]. Modern soy-based infant formulas contain phosphorus and calcium at concentrations that are approximately $20 \%$ higher than those in bovine milk-based infant formulas, and also have higher minimum iron and zinc requirements than bovine milk-based infant formulas [12,14,30]. In a systematic review of the available literature, Vandenplas et al. [30] concluded that feeding modern soy-based infant formula to infants did not result in any negative impact on haemoglobin, zinc, calcium, and overall growth, therefore indicating that current mineral supplementation levels in soy-based infant formula are sufficient to meet infant requirements.

\subsection{Vitamins}

Vitamin requirements for infant formula as per EU legislation are given in Table 5.

Table 5. Vitamin requirements for infant formula [14].

\begin{tabular}{|c|c|c|c|c|}
\hline & \multicolumn{2}{|c|}{ Per $100 \mathrm{~kJ}$} & \multicolumn{2}{|c|}{ Per 100 kcal } \\
\hline & Minimum & Maximum & Minimum & Maximum \\
\hline Vitamin $A(\mu-R E)^{1}$ & 16.7 & 27.2 & 70 & 114 \\
\hline Vitamin D $(\mu \mathrm{g})$ & 0.48 & 0.72 & 2 & 3 \\
\hline Thiamine $(\mu \mathrm{g})$ & 9.6 & 72 & 40 & 300 \\
\hline Riboflavin $(\mu \mathrm{g})$ & 14.3 & 95.6 & 60 & 400 \\
\hline Niacin $(m g)^{2}$ & 0.1 & 0.36 & 0.4 & 1.5 \\
\hline Pantothenic acid (mg) & 0.1 & 0.48 & 0.4 & 2 \\
\hline Vitamin $B_{6}(\mu \mathrm{g})$ & 4.8 & 41.8 & 20 & 175 \\
\hline Biotin $(\mu \mathrm{g})$ & 0.24 & 1.8 & 1 & 7.5 \\
\hline Folate $(\mu \mathrm{g} \text {-DFE })^{3}$ & 3.6 & 11.4 & 15 & 47.6 \\
\hline Vitamin $\mathrm{B}_{12}(\mu \mathrm{g})$ & 0.02 & 0.12 & 0.1 & 0.5 \\
\hline Vitamin C & 0.96 & 7.2 & 4 & 30 \\
\hline Vitamin K & 0.24 & 6 & 1 & 25 \\
\hline Vitamin E (mg $\alpha$ - tocopherol $)^{4}$ & 0.14 & 1.2 & 0.6 & 5 \\
\hline
\end{tabular}

${ }^{1}$ Preformed vitamin A, RE $=$ all trans retinol equivalent; ${ }^{2}$ preformed niacin; ${ }^{3}$ dietary folate equivalent: $1 \mu \mathrm{g}$ $\mathrm{DFE}=1 \mu \mathrm{g}$ food folate $=0.6 \mu \mathrm{g}$ folic acid from formula; ${ }^{4}$ based on vitamin $\mathrm{E}$ activity of RRR- $\alpha$-tocopherol.

Similar to minerals, infant formula must be fortified with vitamins in the case that the innate vitamin contents of the raw materials (proteins, carbohydrates, and lipids) do not meet the requirements detailed in Table 5. During the manufacture of infant formula, ingredients are exposed to heat treatments, which may lead to the degradation of heatlabile vitamins such as vitamin $C$ and thiamine $[8,25]$. Therefore, the use of appropriate overages is important to compensate for any losses that may occur during processing $[8,25]$. Alternatively, heat-labile vitamins may be dry blended with powdered ingredients after these have been subjected to the required heat treatments [8]. 


\subsection{Other Nutrients}

Choline is a precursor for the synthesis of phospholipids, platelet-activating factor, and acetylcholine [25,42]. EU legislation indicates that infant formula must contain $25-50 \mathrm{mg} / 100 \mathrm{kcal}$ of choline [14]. Infant formula may be fortified with choline salts such as choline chloride in the case that raw materials do not contain sufficient amounts [25]. Infant formula must also contain L-carnitine, with a minimum concentration of $1.2 \mathrm{mg} / 100 \mathrm{kcal}$ outlined in EU legislation [14]. It is considered an essential nutrient for neonates as they temporarily lack the capacity for its synthesis and may be added to infant formula in its free form if required [42]. Taurine is a sulphur-containing $\beta$-amino acid with a sulphonic acid group [25]. It is thought to play a role in hepatic function, intestinal fat absorption, and long-term neurological development [25,42]. Taurine is found at higher levels in human milk than in bovine milk, and therefore infant formulas are commonly fortified with same; however, fortification is not essential and the level of taurine in infant formula must not exceed $12 \mathrm{mg} / 100 \mathrm{kcal}[14,25]$. Inositol is a sugar alcohol that has been reported to contribute to several biological functions, including cell signalling, production of phospholipids, and regulation of cell osmolarity [42]. It is currently unknown whether endogenous synthesis of inositol is sufficient to meet requirements in new-born infants, therefore, a minimum of $4 \mathrm{mg} / 100 \mathrm{kcal}$ of inositol is required in infant formula according to EU legislation [14]. Nucleotides, which are structural components of ribonucleic acid (RNA) and deoxyribonucleic acid (DNA), are found in human milk and have been associated with enhancing infant immunity, and consequently are generally added to infant formula $[14,25,42]$.

\section{Digestibility of Infant Formula from Bovine, Caprine, and Plant Sources}

Understanding infant digestion is essential to optimise nutrient delivery from formulated infant nutritional products. Studies of the digestibility of infant formulas enhance the understanding of their degradation and the bio-accessibility of digested nutrients in the GIT [56]. Digestion studies may be carried out in vivo or in vitro, with the latter becoming increasingly popular [56]. While researchers are currently unable to replicate the exact in vivo digestive conditions of infants, in vitro methods offer a series of benefits, including being less time consuming, cost effective, having reduced ethical restrictions, and better accessibility of samples throughout the process [56].

In vitro models of digestion may be classified as dynamic or static [56,63]. Static models are the simplest methods for the simulation of in vivo digestion, where the final digestive products remain within the reaction vessels throughout the process of digestion, while dynamic models such as TIM1 (TNO gastrointestinal model 1) and TIM2 are multicompartmental, replicating peristalsis, gastric emptying, enzyme and fluid secretion, and $\mathrm{pH}$ changes in the stomach during digestion, [56,63]. The advantages and limitations of these models have been described by Minekus et al. [64], Brodkorb et al. [63] and Egger et al. [65], and reviewed in detail by Nguyen et al. [56] and Li et al. [66].

A standardised method for static in vitro digestion has been developed and recently updated based on international consensus by the COST INFOGEST network $[63,64]$. Currently, the INFOGEST method is only applicable to adult digestion [63]. Digestive conditions in infants are known to be different from those in adults, including gastric $\mathrm{pH}$, which in the fasted state has been reported to be $\mathrm{pH} 4-5$ compared to $\mathrm{pH} 2$ in adults; and the availability and concentration of some digestive enzymes [56]. As a result of these differences, and due to variation in the parameters used to simulate infant digestion in previous studies, an in vitro static digestion method based on the INFOGEST protocol has recently been proposed by Ménard et al. [67] which was shown to be physiologically relevant to infant digestion. The following section focuses on the functionality of infant formula with respect to its digestive characteristics, as assessed via in vitro studies of digestion.

Ye et al. [68] used a dynamic in vitro digestion model to compare the gastric digestive properties of infant formulas made with bovine and caprine milk with whey to casein ratios of 60:40 (goat milk infant formula (IFG) 1 and cow milk infant formula (IFC) 1) and 20:80 (IFG2 and IFC2). During gastric digestion, a larger increase in particle size was 
observed for the casein dominant formulas compared to the whey dominant formulas of both species, with IFC2 producing the largest particles [68]. A similar result was reported by Phosanam et al. [69], who showed more extensive aggregation of proteins during the gastric phase of static in vitro digestion with increasing casein to whey ratio in bovine milk-based infant formula. The increase in particle size was indicative of protein aggregation and oil droplet flocculation due to the low $\mathrm{pH}$ and action of pepsin, replicating infant gastric digestion; with the differences observed between the casein and whey dominant formulas due to the higher proportion of casein micelles, which are more sensitive to $\mathrm{pH}$ and pepsin induced aggregation, and lower proportion of whey protein, which can impair aggregation of destabilised casein micelles [68,69]. Phosanam et al. [69] also reported reduced protein and fat digestion during the gastric and intestinal stage in bovine milk-based infant formula with casein to whey ratio of 80:20. While a certain amount of coagulation is desirable to maximise protein digestion through the restriction of gastric emptying, excessive coagulation is undesirable, leading to reduced accessibility of enzymes to their substrate [69].

Bovine milk has previously been reported to produce a firm, dense coagulum during digestion, while caprine milk has been demonstrated to form soft curds, which are more like those produced during the digestion of human milk and are easier to digest [20]. Although protein coagulation was observed using confocal microscopy in the study on bovine and caprine milk-based infant formula by Ye et al. [68], there was no firm clot formation. It was reported that the high fat content of the formulas and homogenisation in their production may have contributed to the observed differences in the structure of the protein coagula [68].

Ye et al. [68] also observed that the rate of protein digestion, particularly of the caseins, was faster in the infant formulas made with caprine milk than those made with bovine milk $(p<0.05)$. After 60 min of digestion, $\sim 40 \%$ of the casein in the goat milk infant formulas remained undigested, while $>50 \%$ of the casein remained undigested in IFC1 and IFC2. Similar results were reported by Hodgkinson et al. [70] using an in vitro static digestion model of infant and young child digestion, whereby after $60 \mathrm{~min}$ of digestion, caseins from caprine milk tended to be more extensively digested than those of bovine milk. This may be attributed to the higher amount of $\beta$-casein and increased casein micelle size in caprine milk compared to bovine milk, leading to differences in casein aggregation and thus improving their susceptibility to pepsin hydrolysis [68,70]. Additionally, whey proteins have been reported to be more resistant to in vitro gastric digestion than caseins, with the digestion of whey proteins commencing in the intestinal phase $[56,68,69]$. This may be due to their structural stability at the low $\mathrm{pH}$ of the stomach and resistance to pepsin hydrolysis [68].

Nguyen et al. [71] used a static in vitro digestion model to compare the digestibility of bovine milk and soy proteins in infant formula. Four model infant nutritional formulations, each containing $1.5 \mathrm{~g} / 100 \mathrm{~mL}$ of protein, with three bovine milk-based formulations containing a WPI to calcium caseinate ratio of 60:40, 40:60, or 20:80, and a soy-based formulation containing SPI. Digestibility of the formulations was evaluated using a $\mathrm{pH}$ drop assay, whereby the rate of digestibility is represented by the extent of the reduction in $\mathrm{pH}$ at the end of the duodenal digestion phase [71]. It was reported that the formulations with a whey to casein ratio of 20:80 showed the greatest reduction in $\mathrm{pH}$, while the soy-based model formula displayed the lowest reduction in $\mathrm{pH}$, demonstrating that the bovine milk-based formula with the highest casein to whey ratio was the most extensively digested following 120 min duodenal digestion, while the soy formula was the least digested formula [71].

The lower digestibility of the soy-based infant formula observed in the study by Nguyen et al. [71] may be attributed to the secondary structure of soy protein. Carbonaro et al. [72] noted lower digestibility of soy protein compared to whole milk protein in an in vitro study of protein digestibility. A negative linear correlation coefficient $(r=-0.980)$ was observed between the extent of $\beta$-sheet secondary structure in each protein 
evaluated and the respective indices of digestibility [72]. Soy proteins contain a higher number of $\beta$-sheets in their secondary structures than milk proteins [72], with these structures being hydrophobic and encouraging protein aggregation, making them less accessible for protease action. While soy-based infant formula also contains anti-nutritional compounds such as trypsin inhibitors which may impair protein digestion, these are largely inactivated by appropriate technological treatments, and therefore should have minimal impact on the digestibility of soy-based infant formula [71,72]. Yang et al. [73] similarly reported a negative linear correlation $(r=-0.91)$ between the extent of $\beta$-sheet conformation in SPI derived from five different varieties of soybean and their in vitro digestibility values. However, the studies by Carbonaro et al. [72] and Yang et al. [73] were both carried out using adult conditions of digestion, and therefore the results may not be directly transferrable to infant digestion of soy infant formula.

Data are very limited on the digestion of rice-based infant formulas. Le Roux et al. [74] investigated the in vitro static digestion of model infant formulas in which $50 \%$ of total protein consisted of a rice protein concentrate and the remaining protein from bovine SMP. The model rice infant formula was reported to be significantly less hydrolysed $(p<0.05)$ at the end of in vitro digestion than a reference infant formula consisting entirely of bovine milk proteins [74]. In addition to improvements in solubility, the digestibility of rice protein may be improved by hydrolysis, as shown by Alsonso-Miravalles et al. [75], who reported significantly higher in vitro intestinal digestibility of a commercially available hydrolysed rice protein infant formula compared to a commercially available soy infant formula $(p<0.05)$.

The rate of lipolysis during infant digestion is determined by the physicochemical characteristics of the oil/water interface, including the surface area of the lipid droplets and the composition of the interfacial layer [76]. As outlined previously, the primary source of lipids in infant formulas are vegetable oils and the composition of the interfacial layer varies depending on the source of protein and emulsifiers used. Studies investigating lipid digestion in infant formula from various sources are limited. Fondaco et al. [77] investigated the in vitro lipid digestion of human milk and four Similac ${ }^{\mathrm{TM}}$ infant formulas (labelled as sensitive, total comfort, advanced, and soy). All four infant formulas were observed to have similar rates of lipolysis, while the rate of lipolysis was observed to be much higher for human milk [77]. The higher rate of lipolysis in human milk was thought to be due to the presence of endogenous bile salt stimulated lipase (BSSL) within the breast milk, which was absent in the formulas. Additionally, the total fatty acid bio-accessibility (the sum of the fatty acids released from the jejunum and ileum) was not significantly different between the sensitive, soy, and total comfort formulas [77]. However, the total fatty acid bio-accessibility was significantly higher for the formula labelled as "advanced"and human milk compared to the other infant formulas [77]. The compositions of the study formulas were not provided; therefore, it is difficult to suggest why the fatty acid bio-accessibility was higher in the "advanced formula compared to the other formulas. However, this study showed similar lipolysis and fatty acid bio-accessibility between the soy infant formula and two bovine milk-based infant formulas [77]. Nguyen et al. [78] similarly reported that there was no significant difference in the total free fatty acids released during in vitro digestion between model soy and bovine milk-based infant formulas. However, a lack of data exists on the lipid digestion of infant formulas in which the lipid emulsions are stabilised by caprine milk protein or hydrolysed rice protein.

There is a lack of studies investigating the digestion of carbohydrates in infant formula. Gnoth et al. [79], demonstrated that HMOs are not digested by enzymes in the GIT, which is essential for their beneficial functions. Wright et al. [80] compared postprandial glycaemic responses to the consumption of human milk, a standard infant formula (Wyeth S-26 Gold Formula) and a reference food in 10 adults as part of a randomised crossover study. The resulting glycaemic index (GI) values were significantly lower than those of the reference food but were not significantly different between human milk and the standard infant formula (GI $=38 \pm 7$ and $34 \pm 7$, respectively; $p=0.3$ ) [80]. In a second randomised 
crossover study, the postprandial glycaemic response was determined for 11 further infant and young child formulas. A wide range of GI values were obtained (18 \pm 3 to $67 \pm 6$ ), with the formulas containing corn syrup solids and/or maltodextrin tending to have higher GI values compared to formulas containing 100\% lactose [80]. However, both studies were carried out in adults due to ethical constraints in conducting such studies in infants. Therefore, further research is required to fully understand the effects of consuming infant formula with a high glycaemic index on infants.

\section{Aspects of Protein Functionality of Relevance to Infant Formula}

The choice of protein used in infant formula depends not only on its nutritional properties but also on its functional properties, which are the physicochemical properties of a protein that affect food characteristics, such as its structure, texture and colloidal stability [19]. These physicochemical properties include solubility, surface activity, and gelation [19]. Infant nutritional formulations are typically homogenised during manufacture, creating an oil-in-water emulsion stabilised by proteins. The proteins adsorb onto the oil/water interface, decreasing tension at the oil/water interface, preventing the coalescence of fat droplets through the formation of protective, electrically charged protein layers [81]. The formation of a stable emulsion is a crucial step in infant formula manufacture, as it ensures stability through subsequent evaporation, spray drying, and powder rehydration, whereas insufficient emulsification will lead to flocculation and coalescence, resulting in the formation of a powder with high levels of free fat and poor reconstitution properties upon drying $[81,82]$. The caseins, particularly $\beta$-casein and $\alpha_{\mathrm{s} 1}$-casein, are known to have excellent surface activity $[19,81]$. Whey proteins are less likely to adsorb at the oil/water interface, particularly in their native globular state [81]. However, they become more flexible with an increased likelihood of adsorption at the oil/water interface following thermal treatments, such as those before homogenisation [81]. At a whey casein ratio of 60:40, it has been reported that casein is preferentially adsorbed at the interfacial layer $[81,82]$. The protein content of the infant formula is important for emulsion stability, as shown by McCarthy et al. [82], who reported that a minimum protein to fat ratio of 0.26 was necessary for emulsion stability during evaporation, with a reduction in the protein to fat ratio from 0.26 to 0.21 , resulting in large increases in fat globule size and creaming rate of the reconstituted powders.

Whey proteins are more heat-labile than caseins, and therefore play an important role in determining the stability and processing performance of infant formula during heat treatment [81]. However, the casein micelles in goat milk have been reported to be less heat stable than those in bovine milk, which is associated with their higher concentration of micellar calcium [23]. Heating of $\beta$-lactoglobulin, the primary whey protein in bovine and caprine milk, to $>60^{\circ} \mathrm{C}$, results in a loss of its $\alpha$-helical structure, exposing the free thiol group embedded in its native globular form [81], leading to protein aggregation due to the formation of disulphide linkages with adjacent $\beta$-lactoglobulin molecules and other proteins.

The thermal stability of infant formula is affected by mineral content, in addition to changes in $\mathrm{pH}$, lactose, and protein concentration. McSweeney et al. [83] demonstrated the effect of $\mathrm{pH}$ on HCT with the sequential addition of ingredients for a whey dominant infant formula. It was reported that for a reconstituted SMP and demineralised whey blend, the maximum HCT ( $30 \mathrm{~min})$ was exhibited at a $\mathrm{pH}$ of 6.8 . The addition of lactose to the protein blend reduced the maximum HCT, and following the addition of both lactose and $\mathrm{CaCl}_{2}$, the maximum HCT shifted to a more alkaline $\mathrm{pH}(\sim 7.2)$ [83]. The HCT of the emulsion formed by the protein ingredients, lactose, $\mathrm{CaCl}_{2}$, and soy oil was reported to be slightly lower than that of the oil-free version due to heat-induced interactions of whey proteins with proteins adsorbed at the interfacial layer [83]. A similar approach was also taken for casein dominant infant formula ingredients. As with the whey dominant formula, the addition of lactose to reconstituted SMP was shown to decrease the HCT; however, the addition of $\mathrm{CaCl}_{2}$ and homogenisation were observed to have a lesser effect on the HCT of 
the casein dominant formula due to the lower level of calcium salt added to meet calcium requirements, and the lower concentration of whey protein for heat-induced interaction with the interfacial layer [83]. The authors concluded that the whey dominant formula would require adjustment to $\mathrm{pH}>6.9$ to ensure stability during thermal processing, while the casein dominant formula would remain stable at the unadjusted $\mathrm{pH}$ of 6.7 [83].

Due to structural differences, the soy seed storage proteins, glycinin and $\beta$-conglycinin are known to differ in their functional characteristics [27]. For example, glycinin is known to form stronger gels, while $\beta$-conglycinin has better emulsion stabilising capability than glycinin [27]. As for milk proteins, the thermal stability of soy proteins is affected by $\mathrm{pH}$ and protein concentration in addition to ionic strength; for example, Ryan et al. [61] demonstrated that the HCT of SPI increased with increasing $\mathrm{pH}$ in the range of 6.4-7.5. Increasing protein concentration from 1.8 to $7.2 \% w / w$ was also shown to significantly reduce the heat stability of SPI, attributed to increased protein-protein interactions and aggregation [61]. In a separate study, Ryan et al. [84] investigated the thermal behaviour of emulsions stabilised with SPI. Similarly, the HCT of the model emulsions increased with increasing $\mathrm{pH}$ in the range 6.4-7.5, while the addition of calcium salts decreased emulsion stability [84].

The poor solubility of intact rice proteins limits their use as functional food ingredients; therefore, rice proteins are typically pre-hydrolysed for use in infant formula to improve their functional properties [31-33]. The physicochemical properties of commercially available rice proteins were recently investigated by Amagliani et al. [31]. Solubility of the rice protein concentrates was reported to be poor, with solubility of a $1 \% w / v$ dispersion ranging from $2-35 \%$ at $\mathrm{pH}$ in the range $2-8$ [31]. In contrast, the solubility of the hydrolysed rice endosperm proteins was much greater, ranging from $95-100 \%$ across the $\mathrm{pH}$ range studied, which was attributed to the decrease in molecular weight and increased number of ionisable groups created by enzymatic hydrolysis [31]. Rice bran protein hydrolysate also showed improvements in solubility compared to the intact rice protein concentrate, displaying solubility of $63.3-85.8 \%$ in the $\mathrm{pH}$ range studied. However, while enzymatic hydrolysis is beneficial to improve solubility, excessive hydrolysis has been reported to impair other functional properties of protein, such as emulsification, and may lead to bitterness due to an increased concentration of hydrophobic amino acids and small peptides [32]. Amagliani et al. [31] also reported on the heat stability of the rice protein ingredients, which were reported to be extremely heat stable, with no aggregation/flecking following heat treatment at $140{ }^{\circ} \mathrm{C}$ for $30 \mathrm{~min}$.

\section{Metabolomics and Infant Formula}

Metabolomics is a field of research involving the high-throughput identification and quantification of low-molecular-weight $(<1500 \mathrm{Da})$ metabolites within the metabolome $[85,86]$. These low-molecular-weight molecules are diverse and include peptides, amino acids, organic acids, nucleic acids, vitamins, polyphenols, and sugars $[85,86]$. Three of the most widely used methodologies for metabolomic analysis are high-resolution proton nuclear magnetic resonance (NMR) spectroscopy $\left({ }^{1} \mathrm{H}\right.$ NMR), gas chromatography mass spectrometry (GC-MS), and liquid chromatography mass spectrometry (LC-MS) $[85,86]$. Each method is associated with a series of advantages and disadvantages. For example, limitations of ${ }^{1} \mathrm{H}$ NMR include its sensitivity and requirement for large sample size; however, it is a non-destructive method with minimal sample preparation requirements [85,86]. In comparison, LC-MS and GC-MS are more sensitive methods capable of detecting both organic and inorganic molecules, but both methods are slower and novel compound identification is more difficult [86].

The original primary use of metabolomics was in clinical or pharmaceutical applications. However, the use of metabolomics in food science and nutrition applications is increasingly being used due to its ability to simultaneously characterise a large number of compounds in food matrices, providing a comprehensive molecular picture of food composition [86]. For example, the metabolite profile of bovine milk has been studied with 
the identification of over 2000 different metabolites [87]. Studies have found that a variety of these metabolites can act as markers for herd health, the prediction of techno-functional properties, quality, adulteration, and authentication $[85,88]$. The metabolite profile of human milk has also been explored, providing information on its biochemical variability with regard to the mother's phenotype, disease, diet, and lifestyle $[88,89]$.

However, few studies have investigated the metabolite profile of infant formula. Zhao et al. [90] used ${ }^{1} \mathrm{H}$ NMR, with multivariate statistical analysis, to investigate the compositional differences between five different commercially available brands of infant formula (coded I, G, S, O, and W) and whole bovine milk. Formate, ascorbate, creatinine, glycerol, lactose, nicotinate, $\alpha$-glucose, $\beta$-glucose, taurine, and two unknown compounds (U7 and U12) were present at much higher concentrations in the infant formulas than in bovine milk [90]. This study also demonstrated variations in both labelled and unlabelled components in the infant formulas analysed. For example, a comparison of the five infant formulas showed that formulas from brands I and $\mathrm{G}$ were similar in composition compared to other pair-groups [90], with these two infant formulas characterised by high levels of tryptophan and tyrosine, detected as free amino acids or amino acid complexes bound to small peptides, which were absent in other brands [90]. Additionally, despite not being listed in the ingredients, sucrose signals were discovered in the NMR spectrum of the $\mathrm{W}$ branded formula. Furthermore, the branched-chain amino acids (BCAAs) valine and isoleucine were found in higher concentrations in brand $S$ than the other brands of infant formulas [90].

Scano et al. [91] and Garwolinska et al. [92] also performed metabolomic analysis of various infant formulas, but in this case, compared it to the metabolite profile of human milk samples. In the study by Scano et al. [91], the metabolite profiles of 31 formula samples containing bovine milk proteins and lactose (17 first age $<6$ months and 14 follow on age $>6$ months) from eight brands were compared with breastmilk samples from 31 healthy lactating women using GC-MS, followed by multivariate statistical analysis. The presence of galactose, malic acid, and mannitol were determined to be the most discriminatory metabolites in the formulas, while higher levels of amino acids, urea, myo-inositol, and scyllo-inositol were found in breast milk samples [91]. In the study by Garwolinska et al. [92], NMR spectroscopy was performed on formula samples from seven brands, including four bovine milk-based and three caprine milk-based infant formula brands including samples of first infant formula ( $<6$ months), follow on formula (7-12 months) and young child formula (>12 months). Samples from the caprine milkbased formulas were found to have higher concentrations of several amino acids (methionine, alanine, isoleucine, tryptophan, and valine), taurine, nucleotides, creatine phosphate, succinate, and maltose, but levels of $\mathrm{N}$-acetylglucosamine, acetone, galactose, sucrose, glucose, phenylalanine, and sn-glycero-3-phosphocholine were lower compared to bovine milk-based formulas [92]. Significantly higher levels of glucose and acetone $(p<0.001)$ were found in bovine milk-based formulas compared to human milk, and isoleucine was found to be significantly higher in concentration in caprine milk-based formulas compared to human milk [92]. Both studies reported that differences in the metabolite profile were more evident between different brands rather than formulas targeted at different age groups [91,92].

Metabolomic analysis of infant formula has the potential for use in the detection of adulterants or chemical changes during the production and storage of infant formula, therefore enhancing product quality and safety [90]. Furthermore, metabolomic analysis provides a deeper understanding of infant formula composition, holding the ability to identify and quantify multiple minor, but potentially important components simultaneously, many of which are already associated with benefits to infant health and development, such as taurine and nucleotides [25,90]. However, further studies on the metabolomic analysis of infant formula are required, particularly in infant formulas from non-bovine sources to gain further knowledge on the full range of metabolites present within each type of infant formula, and the differences that occur between formulas manufactured from different 
protein sources. This information can then be used for more comprehensive comparison to breastmilk, enabling enhanced optimisation of infant formula composition with the aim of matching the growth and development outcomes of breastfed infants.

\section{Alternative Protein Sources with Potential Use in Infant Formula Manufacture}

While bovine milk-based infant formula remains the most widely used formula type for infant feeding, there is increasing demand for alternatively sourced formulas due to increasing environmental concerns and adoption of alternative diets [11]. Plant-based formulas currently available commercially have limitations; for example, soy-based formula is not suitable for infants with CPMA, as 10-14\% of infants with CMPA are also known to be allergic to soy $[12,13]$. Furthermore, soy-based formula contains isoflavones, which have estrogenic activity and so far, evidence regarding the safety of their consumption by infants remains inconclusive [13,30]. Additionally, rice proteins may contain arsenic, and their low solubility confers technical challenges during formula manufacture [32,75]. Consequently, there is increasing interest in the development of plant-based alternative formulas. Recently, a patent was filed for a potato-based infant formula, which is hypoallergenic, and therefore suitable for infants with CMPA [93]. Le Roux et al. [74] investigated the use of plant protein in infant formula with the partial replacement of the whey protein with pea, fava bean, potato, and rice proteins. Lately, Alonso-Miravalles et al. [75] demonstrated the potential for lentil protein isolates in the formulation of next-generation infant nutritional products, which was shown to have a comparable macronutrient composition, similar reconstitution properties, and greater thermal stability than commercially available soy- and rice-based infant formula.

In addition to caprine milk, several other non-bovine milks have gained interest for their potential use in infant formula manufacture. For example, camel milk, like human milk, does not contain $\beta$-lactoglobulin and has previously been suggested as an alternative protein source for infants with CMPA due to an absence of immunological similarity between it and bovine milk $[8,94,95]$. Equine milk has also been investigated as a prospective source of ingredients for infant formula manufacture due to its superior similarity with human milk compared to bovine milk, namely its lower protein content, more favourable whey: casein ratio, higher concentration of lactose and lower ash content $[8,20,95]$. However, the use of non-bovine milk as a source of ingredients for infant formula remains hindered by their comparably low production volumes [8].

\section{Conclusions}

This review has examined differences in the composition of infant formulas from bovine, caprine, and plant sources, and the key differences between these formulas in terms of protein quality, digestibility and protein functionality. Gaps in our current knowledge have been identified, particularly in terms of protein quality and digestibility of infant formulas from plant sources. Finally, metabolomic analysis of infant formula has been identified as an emerging technique that has the potential to support optimisation in the formulation of infant nutritional products, to enhance their nutritional quality and safety for consumers.

Author Contributions: Writing—original draft preparation, M.E.B.; writing—review and editing, J.A.O. and T.F.O.; supervision, J.A.O. and T.F.O. All authors have read and agreed to the published version of the manuscript.

Funding: This research received no external funding.

Institutional Review Board Statement: Not applicable.

Conflicts of Interest: The authors declare no conflict of interest. 


\section{References}

1. Agostoni, C.; Braegger, C.; Decsi, T.; Kolacek, S.; Koletzko, B.; Michaelsen, K.F.; Mihatsch, W.; Moreno, L.A.; Puntis, J.; Shamir, R.; et al. Breast-feeding: A commentary by the ESPGHAN Committee on Nutrition. J. Pediatr. Gastroenterol. Nutr. 2009, 49, 112-125. [CrossRef] [PubMed]

2. Victora, C.G.; Bahl, R.; Barros, A.J.; França, G.V.; Horton, S.; Krasevec, J.; Murch, S.; Sankar, M.J.; Walker, N.; Rollins, N.C. Breastfeeding in the 21st century: Epidemiology, mechanisms, and lifelong effect. Lancet 2016, 387, 475-490. [CrossRef]

3. Eidelman, A.I.; Schanler, R.J. Breastfeeding and the use of human milk. Pediatrics 2012, 129, e827-e841. [CrossRef]

4. World Health Organisation. Nutrition through the life-course. In Essential Nutrition Actions: Mainstreaming Nutrition through the Lifecourse; WHO: Geneva, Switzerland, 2019; pp. 33-139.

5. Scientific Advisory Committee on Nutrition. Feeding in the First Year of Life. Available online: https://assets.publishing.service. gov.uk/government/uploads/system/uploads/attachment_data/file/725530/SACN_report_on_Feeding_in_the_First_Year_ of_Life.pdf (accessed on 20 February 2021).

6. McMahon, L.; McGrane, K.; McKenna, P.; Turner, M. Irish Maternity Indicator System National Report. 2019. Available online: https:/ / www.hse.ie/eng/about/who/acute-hospitals-division/woman-infants/national-reports-on-womens-health/ imis-national-report-2019.pdf (accessed on 18 February 2021).

7. European Union Regulation (EU) No. 609/2013 of the European Parliament and of the Council of 12 June 2013 on Food Intended for Infants and Young Children, Food for Special Medical Purposes, and Total Diet Replacement for Weight Control and Repealing Council Directive 92/52/EEC, Commission Directives 96/8/EC, 1999/21/EC, 2006/125/EC and 2006/141/EC, Directive 2009/39/EC of the European Parliament and of the Council and Commission Regulations (EC) No. 41/2009 and (EC) No. 953/2009. Available online: https:/ / eur-lex.europa.eu/legal-content/EN/TXT/PDF/?uri=CELEX:02013R0609-20170711 \&from $=$ EN (accessed on 21 February 2021).

8. Crowley, S.V.; Kelly, A.L.; Lucey, J.A.; O'Mahony, J.A. Potential Applications of Non-Bovine Mammalian Milk in Infant Nutrition. In Handbook of Milk of Non-Bovine Mammals, 2nd ed.; Park, Y.W., Haenlein, G.F.W., Wendorff, W.L., Eds.; John Wiley \& Sons: Hoboken, UK, 2017; pp. 625-654.

9. Schoemaker, A.A.; Sprikkelman, A.B.; Grimshaw, K.E.; Roberts, G.; Grabenhenrich, L.; Rosenfeld, L.; Siegert, S.; Dubakiene, R.; Rudzeviciene, O.; Reche, M.; et al. Incidence and Natural History of Challenge-Proven Cow's Milk Allergy in European Children-EuroPrevall Birth Cohort. Allergy 2015, 70, 963-972. [CrossRef]

10. Koletzko, S.; Niggemann, B.; Arato, A.; Dias, J.A.; Heuschkel, R.; Husby, S.; Mearin, M.L.; Papadopoulou, A.; Ruemmele, F.M.; Staiano, A.; et al. Diagnostic Approach and Management of Cow's-Milk Protein Allergy in Infants and Children: ESPGHAN GI Committee Practical Guidelines. J. Pediatr. Gastroenterol. Nutr. 2012, 55, 221-229. [CrossRef]

11. Janssen, M.; Busch, C.; Rodiger, M.; Hamm, U. Motives of Consumers Following a Vegan Diet and their Attitudes Towards Animal Agriculture. Appetite 2016, 105, 643-651. [CrossRef]

12. Bhatia, J.; Greer, F.; Comm, N. Use of Soy Protein-based Formulas in Infant Feeding. Pediatrics 2008, 121, 1062-1068. [CrossRef]

13. Agostoni, C.; Axelsson, I.; Goulet, O.; Koletzko, B.; Michaelsen, K.F.; Puntis, J.; Rieu, D.; Rigo, J.; Shamir, R.; Szajewska, H.; et al. Soy Protein Infant Formulae and Follow-on Formulae: A commentary by the ESPGHAN Committee on Nutrition. J. Pediatr. Gastroenterol. Nutr. 2006, 42, 352-361. [CrossRef]

14. European Union. Commission Delegated Regulation (EU) 2016/127 of 25th September 2015 Supplementing Regulation (EU) No 609/2013 of the European Parliament and of the Council as Regards the Specific Compositional and Information Requirements for Infant Formula and Follow-On Formula and as Regards Requirements on Information Relating to Infant and Young Child Feeding. Available online: https:/ / eur-lex.europa.eu/legal-content/EN/TXT/PDF/?uri=CELEX:02016R0127-20190612\&from= EN (accessed on 21 February 2021).

15. Food and Drug Administration. Code of Federal Regulations, Title 21, Chapter 21, Subchapter B, Part 107-Infant Formula. Available online: https:/ /www.ecfr.gov/current/title-21/chapter-I/subchapter-B/part-107 (accessed on 26 October 2021).

16. Joint FAO/WHO Codex Alimentarius Commission. Codex Alimentarius Standard for Infant Formula and Formulas for Special Medical Purposes Intended for Infants CXS 72-1981. Available online: https: / / www.fao.org/fao-who-codexalimentarius / shproxy / en / ?lnk=1\&url=https $\% 253 \mathrm{~A} \% 252 \mathrm{~F} \% 252 \mathrm{Fw}$ orkspace.fao.org $\% 252 \mathrm{Fsites} \% 252 \mathrm{Fcodex} \% 252 \mathrm{FStandards} \% 252 \mathrm{FCXS} \% 2 \mathrm{~B} 72-$ 1981\%252FCXS_072e.pdf (accessed on 26 October 2021).

17. Dupont, C.; Bocquet, A.; Tomé, D.; Bernard, M.; Campeotto, F.; Dumond, P.; Essex, A.; Frelut, M.-L.; Guénard-Bilbault, L.; Lack, G.; et al. Hydrolyzed Rice Protein-Based Formulas, a Vegetal Alternative in Cow's Milk Allergy. Nutrients 2020, $12,2654$. [CrossRef]

18. Prosser, C.G. Compositional and Functional Characteristics of Goat Milk and Relevance as a Base for Infant Formula. J. Food Sci. 2021, 86, 257-265. [CrossRef]

19. Fox, P.F.; Uniacke-Lowe, T.; McSweeney, P.L.H.; O'Mahony, J.A. Dairy Chemistry and Biochemistry, 2nd ed.; Springer: Cham, Switzerland, 2015.

20. Claeys, W.L.; Verraes, C.; Cardoen, S.; De Block, J.; Huyghebaert, A.; Raes, K.; Dewettinck, K.; Herman, L. Consumption of Raw or Heated Milk from Different Species: An Evaluation of the Nutritional and Potential Health Benefits. Food Control 2014, 42, 188-201. [CrossRef]

21. Park, Y.W. Goat Milk-Chemistry and Nutrition. In Handbook of Milk of Non-Bovine Mammals, 2nd ed.; Park, Y.W., Hanlein, G.F.W., Wendorff, W.L., Eds.; John Wiley \& Sons: Hoboken, UK, 2017; pp. 42-83. 
22. Amigo, L.; Fontecha, J. Milk: Goat Milk. In Encyclopedia of Dairy Sciences, 2nd ed.; Fuquay, J.F., Fox, P.F., McSweeney, P.L.H., Eds.; Academic Press: London, UK, 2011; Volume 3, pp. 484-493.

23. Park, Y.W.; Juárez, M.; Ramos, M.; Haenlein, G.F.W. Physico-chemical characteristics of goat and sheep milk. Small Rumin. Res. 2007, 68, 88-113. [CrossRef]

24. O'Callaghan, D.M.; O'Mahony, J.A.; Ramanujam, K.S.; Burgher, A.M. Dehydrated Dairy Products:Infant Formulae. In Encyclopedia of Dairy Sciences, 2nd ed.; Fuquay, J.F., Fox, P.F., McSweeney, P.L.H., Eds.; Academic Press: London, UK, 2011; Volume 2, pp. 135-145.

25. McSweeney, S.; O’Regan, J.; O'Callaghan, D. Nutritional Formulae for Infants and Young Children. In Milk and Dairy Products in Human Nutrition: Production, Composition and Health; Park, Y.W., Haenlein, G.F.W., Eds.; Wiley-Blackwell: Chichester, UK, 2013; pp. 458-476.

26. EFSA Panel on Dietetic Products Nutrition and Allergies. Scientific Opinion on the Suitability of Goat Milk Protein as a Source of Protein in infant formulae and in follow-on formulae. EFSA J. 2012, 10, 2603. [CrossRef]

27. Medic, J.; Atkinson, C.; Hurburgh, C.R. Current Knowledge in Soybean Composition. J. Am. Oil. Chem. Soc. 2014, 91, 363-384. [CrossRef]

28. Mojica, L.; Dia, V.P.; de Majía, E.G. Soy Proteins. In Applied Food Protein Chemistry; Ustunol, Z., Ed.; Wiley-Blackwell: Chicester, UK, 2014; pp. 141-192.

29. Ma, C.Y. Soybean: Soy Concentrates and Isolates. In Encyclopedia of Food Grains, 2nd ed.; Wrigley, C.W., Corke, H., Seetharaman, K., Faubion, J., Eds.; Academic Press: Oxford, UK, 2016; Volume 3, pp. 482-488.

30. Vandenplas, Y.; Castrellon, P.G.; Rivas, R.; Gutiérrez, C.J.; Garcia, L.D.; Jimenez, J.E.; Anzo, A.; Hegar, B.; Alarcon, P. Safety of soya-based infant formulas in children. Br. J. Nutr. 2014, 111, 1340-1360. [CrossRef]

31. Amagliani, L.; O’Regan, J.; Schmitt, C.; Kelly, A.L.; O’Mahony, J.A. Characterisation of the physicochemical properties of intact and hydrolysed rice protein ingredients. J. Cereal Sci. 2019, 88, 16-23. [CrossRef]

32. Amagliani, L.; O'Regan, J.; Kelly, A.L.; O'Mahony, J.A. The composition, extraction, functionality and applications of rice proteins: A review. Trends Food Sci. Technol. 2017, 64, 1-12. [CrossRef]

33. Romero, M.V. Rice Proteins. In Applied Food Protein Chemistry; Ustunol, Z., Ed.; Wiley-Blackwell: Chicester, UK, 2015 ; pp. 305-322.

34. Boye, J.; Wijesinha-Bettoni, R.; Burlingame, B. Protein quality evaluation twenty years after the introduction of the protein digestibility corrected amino acid score method. Br. J. Nutr. 2012, 108, S183-S211. [CrossRef]

35. FAO Expert Consultation. Dietary Protein Quality Evaluation in Human Nutrition. Available online: https://www.fao.org/ag/ humannutrition/35978-02317b979a686a57aa4593304ffc17f06.pdf (accessed on 20 March 2021).

36. Mathai, J.K.; Liu, Y.H.; Stein, H.H. Values for digestible indispensable amino acid scores (DIAAS) for some dairy and plant proteins may better describe protein quality than values calculated using the concept for protein digestibility-corrected amino acid scores (PDCAAS). Br. J. Nutr. 2017, 117, 490-499. [CrossRef]

37. Maathuis, A.; Havenaar, R.; He, T.; Bellmann, S. Protein Digestion and Quality of Goat and Cow Milk Infant Formula and Human Milk Under Simulated Infant Conditions. J. Pediatr. Gastroenterol. Nutr. 2017, 65, 661-666. [CrossRef]

38. Lien, E.L. Infant formulas with increased concentrations of alpha-lactalbumin. Am. J. Clin. Nutr. 2003, 77, 1555S-1558S. [CrossRef]

39. Lönnerdal, B. Infant formula and infant nutrition: Bioactive proteins of human milk and implications for composition of infant formulas. Am. J. Clin. Nutr. 2014, 99, 712s-717s. [CrossRef]

40. Lönnerdal, B.; Lien, E.L. Nutritional and physiologic significance of alpha-lactalbumin in infants. Nutr. Rev. 2003, 61, 295-305. [CrossRef]

41. Davis, A.M.; Harris, B.J.; Lien, E.L.; Pramuk, K.; Trabulsi, J. Alpha-Lactalbumin-rich infant formula fed to healthy term infants in a multicenter study: Plasma essential amino acids and gastrointestinal tolerance. Eur. J. Clin. Nutr. 2008, 62, 1294-1301. [CrossRef]

42. EFSA Panel on Dietetic Products Nutrition and Allergies. Scientific Opinion on the Essential Composition of Infant and Follow-on Formulae. EFSA J. 2014, 12, 3760. [CrossRef]

43. Hofman, D.L.; Van Buul, V.J.; Brouns, F. Nutrition, Health, and Regulatory Aspects of Digestible Maltodextrins. Crit. Rev. Food Sci. Nutr. 2016, 56, 2091-2100. [CrossRef]

44. Salvatore, S.; Savino, F.; Singendonk, M.; Tabbers, M.; Benninga, M.A.; Staiano, A.; Vandenplas, Y. Thickened infant formula: What to know. Nutrition 2018, 49, 51-56. [CrossRef]

45. Giorgio, D.; Di Trana, A.; Claps, S. Oligosaccharides, polyamines and sphingolipids in ruminant milk. Small Rumin. Res. 2018, 160, 23-30. [CrossRef]

46. Bode, L. Human milk oligosaccharides: Every baby needs a sugar mama. Glycobiology 2012, 22, 1147-1162. [CrossRef]

47. Bych, K.; Miks, M.H.; Johanson, T.; Hederos, M.J.; Vigsnaes, L.K.; Becker, P. Production of HMOs using microbial hosts-From cell engineering to large scale production. Curr. Opin. Biotechnol. 2019, 56, 130-137. [CrossRef]

48. Delplanque, B.; Gibson, R.; Koletzko, B.; Lapillonne, A.; Strandvik, B. Lipid Quality in Infant Nutrition: Current Knowledge and Future Opportunities. J. Pediatr. Gastroenterol. Nutr. 2015, 61, 8-17. [CrossRef] [PubMed]

49. Heird, W.C.; Lapillonne, A. The Role of Essential Fatty Acids in Development. Annu. Rev. Nutr. 2005, 25, 549-571. [CrossRef] [PubMed]

50. Bar-Yoseph, F.; Lifshitz, Y.; Cohen, T. Review of sn-2 palmitate oil implications for infant health. Prostaglandins Leukot. Essent. Fat. Acids 2013, 89, 139-143. [CrossRef] [PubMed] 
51. Bourlieu, C.; Bouzerzour, K.; Ferret-Bernard, S.; Le Bourgot, C.; Chever, S.; Menard, O.; Deglaire, A.; Cuinet, I.; Le Ruyet, P.; Bonhomme, C.; et al. Infant formula interface and fat source impact on neonatal digestion and gut microbiota. Eur. J. Lipid Sci. Technol. 2015, 117, 1500-1512. [CrossRef]

52. Chen, M.; Sun, Q. Current knowledge in the stabilization/destabilization of infant formula emulsions during processing as affected by formulations. Trends Food Sci. Technol. 2021, 109, 435-447. [CrossRef]

53. Gallier, S.; Tolenaars, L.; Prosser, C. Whole Goat Milk as a Source of Fat and Milk Fat Globule Membrane in Infant Formula. Nutrients 2020, 12, 3486. [CrossRef]

54. Lopez, C.; Menard, O. Human milk fat globules: Polar lipid composition and in situ structural investigations revealing the heterogeneous distribution of proteins and the lateral segregation of sphingomyelin in the biological membrane. Colloids Surf. $B$ Biointerfaces 2011, 83, 29-41. [CrossRef]

55. Walter, L.; Shrestha, P.; Fry, R.; Leury, B.J.; Logan, A. Lipid metabolic differences in cows producing small or large milk fat globules: Fatty acid origin and degree of saturation. J. Dairy Sci. 2020, 103, 1920-1930. [CrossRef]

56. Nguyen, T.T.P.; Bhandari, B.; Cichero, J.; Prakash, S. A comprehensive review on in vitro digestion of infant formula. Food Res. Int. 2015, 76, 373-386. [CrossRef]

57. Gallier, S.; Vocking, K.; Post, J.A.; Van De Heijning, B.; Acton, D.; Van Der Beek, E.M.; Van Baalen, T. A novel infant milk formula concept: Mimicking the human milk fat globule structure. Colloids Surf. B Biointerfaces 2015, 136, 329-339. [CrossRef]

58. Prosser, C.G.; Svetashev, V.I.; Vyssotski, M.V.; Lowry, D.J. Composition and distribution of fatty acids in triglycerides from goat infant formulas with milk fat. J. Diary Sci. 2010, 93, 2857-2862. [CrossRef]

59. Amagliani, L.; O'Regan, J.; Keny, A.L.; O'Mahony, J.A. Composition and protein profile analysis of rice protein ingredients. J. Food Compos. Anal. 2017, 59, 18-26. [CrossRef]

60. Omoarukhe, E.D.; On-Nom, N.; Grandison, A.S.; Lewis, M.J. Effects of different calcium salts on properties of milk related to heat stability. Int. J. Dairy Technol. 2010, 63, 504-511. [CrossRef]

61. Ryan, M.; McEvoy, E.; Duignan, S.; Crowley, C.; Fenelon, M.; O'Callaghan, D.M.; FitzGerald, R.J. Thermal stability of soy protein isolate and hydrolysate ingredients. Food Chem. 2008, 108, 503-510. [CrossRef]

62. Gilani, G.S.; Xiao, C.W.; Cockell, K.A. Impact of Antinutritional Factors in Food Proteins on the Digestibility of Protein and the Bioavailability of Amino Acids and on Protein Quality. Br. J. Nutr. 2012, 108, S315-S332. [CrossRef]

63. Brodkorb, A.; Egger, L.; Alminger, M.; Alvito, P.; Assuncao, R.; Ballance, S.; Bohn, T.; Bourlieu-Lacanal, C.; Boutrou, R.; Carriere, F.; et al. INFOGEST static in vitro simulation of gastrointestinal food digestion. Nat. Protoc. 2019, 14, 991-1014. [CrossRef]

64. Minekus, M.; Alminger, M.; Alvito, P.; Ballance, S.; Bohn, T.; Bourlieu, C.; Carriere, F.; Boutrou, R.; Corredig, M.; Dupont, D.; et al. A standardised static in vitro digestion method suitable for food-An international consensus. Food Funct. 2014, 5, 1113-1124. [CrossRef]

65. Egger, L.; Menard, O.; Baumann, C.; Duerr, D.; Schlegel, P.; Stoll, P.; Vergeres, G.; Dupont, D.; Portmann, R. Digestion of milk proteins: Comparing static and dynamic in vitro digestion systems with in vivo data. Food Res. Int. 2019, 118, 32-39. [CrossRef]

66. Li, C.; Yu, W.W.; Wu, P.; Chen, X.D. Current in vitro digestion systems for understanding food digestion in human upper gastrointestinal tract. Trends Food Sci. Technol. 2020, 96, 114-126. [CrossRef]

67. Menard, O.; Bourlieu, C.; De Oliveira, S.C.; Dellarosa, N.; Laghi, L.; Carriere, F.; Capozzi, F.; Dupont, D.; Deglaire, A. A first step towards a consensus static in vitro model for simulating full-term infant digestion. Food Chem. 2018, 240, 338-345. [CrossRef]

68. Ye, A.Q.; Cui, J.; Carpenter, E.; Prosser, C.; Singh, H. Dynamic in vitro gastric digestion of infant formulae made with goat milk and cow milk: Influence of protein composition. Int. Dairy J. 2019, 97, 76-85. [CrossRef]

69. Phosanam, A.; Chandrapala, J.; Huppertz, T.; Adhikari, B.; Zisu, B. In vitro digestion of infant formula model systems: Influence of casein to whey protein ratio. Int. Dairy J. 2021, 117, 105008. [CrossRef]

70. Hodgkinson, A.J.; Wallace, O.A.M.; Boggs, I.; Broadhurst, M.; Prosser, C.G. Gastric digestion of cow and goat milk: Impact of infant and young child in vitro digestion conditions. Food Chem. 2018, 245, 275-281. [CrossRef]

71. Nguyen, T.T.P.; Bhandari, B.; Cichero, J.; Prakash, S. Gastrointestinal digestion of dairy and soy proteins in infant formulas: An in vitro study. Food Res. Int. 2015, 76, 348-358. [CrossRef]

72. Carbonaro, M.; Maselli, P.; Nucara, A. Relationship between digestibility and secondary structure of raw and thermally treated legume proteins: A Fourier transform infrared (FT-IR) spectroscopic study. Amino Acids 2012, 43, 911-921. [CrossRef]

73. Yang, Y.; Wang, Z.J.; Wang, R.; Sui, X.N.; Qi, B.K.; Han, F.F.; Li, Y.; Jiang, L.Z. Secondary Structure and Subunit Composition of Soy Protein In Vitro Digested by Pepsin and Its Relation with Digestibility. BioMed Res. Int. 2016, 2016, 11. [CrossRef]

74. Le Roux, L.; Chacon, R.; Dupont, D.; Jeantet, R.; Deglaire, A.; Nau, F. In vitro static digestion reveals how plant proteins modulate model infant formula digestibility. Food Res. Int. 2020, 130, 108917. [CrossRef]

75. Alonso-Miravalles, L.; Barone, G.; Waldron, D.; Bez, J.; Joehnke, M.S.; Petersen, I.L.; Zannini, E.; Arendt, E.K.; O’Mahony, J.A. Formulation, Pilot-Scale Preparation, Physicochemical Characterisation and Digestibility of a Lentil Protein-Based Model Infant Formula Powder. J. Sci. Food Agric. 2021. [CrossRef]

76. Bourlieu, C.; Menard, O.; De La Chevasnerie, A.; Sams, L.; Rousseau, F.; Madec, M.-N.; Robert, B.; Deglaire, A.; Pezennec, S.; Bouhallab, S.; et al. The structure of infant formulas impacts their lipolysis, proteolysis and disintegration during in vitro gastric digestion. Food Chem. 2015, 182, 224-235. [CrossRef]

77. Fondaco, D.; AlHasawi, F.; Lan, Y.; Ben-Elazar, S.; Connolly, K.; Rogers, M.A. Biophysical Aspects of Lipid Digestion in Human Breast Milk and Similac ${ }^{\mathrm{TM}}$ Infant Formulas. Food Biophys. 2015, 10, 282-291. [CrossRef] 
78. Nguyen, T.T.P.; Bhandari, B.; Cichero, J.; Prakash, S. In vitro lipolysis of dairy and soy based infant formula. Food Res. Int. 2018, 106, 696-705. [CrossRef] [PubMed]

79. Gnoth, M.J.; Kunz, C.; Kinne-Saffran, E.; Rudloff, S. Human milk oligosaccharides are minimally digested in vitro. J. Nutr. 2000, 130, 3014-3020. [CrossRef] [PubMed]

80. Wright, C.J.; Atkinson, F.S.; Ramalingam, N.; Buyken, A.E.; Brand-Miller, J.C. Effects of human milk and formula on postprandial glycaemia and insulinaemia. Eur. J. Clin. Nutr. 2015, 69, 939-943. [CrossRef] [PubMed]

81. Fenelon, M.A.; Hickey, R.M.; Buggy, A.; McCarthy, N.; Murphy, E.G. Whey Proteins in Infant Formula. In Whey Proteins: From Milk to Medicine; Deeth, H.C., Bansal, N., Eds.; Academic Press: London, UK, 2019; pp. 439-494.

82. McCarthy, N.A.; Kelly, A.L.; O'Mahony, J.A.; Hickey, D.K.; Chaurin, V.; Fenelon, M.A. Effect of protein content on emulsion stability of a model infant formula. Int. Dairy J. 2012, 25, 80-86. [CrossRef]

83. McSweeney, S.L.; Mulvihill, D.M.; O'Callaghan, D.M. The influence of $\mathrm{pH}$ on the heat-induced aggregation of model milk protein ingredient systems and model infant formula emulsions stabilized by milk protein ingredients. Food Hydrocoll. 2004, 18, 109-125. [CrossRef]

84. Ryan, M.; McEvoy, E.; McSweeney, S.L.; O'Callaghan, D.M.; FitzGerald, R.J. Thermal behavior of emulsions manufactured with soy protein ingredients. Food Res. Int. 2008, 41, 813-818. [CrossRef]

85. Sundekilde, U.K.; Larsen, L.B.; Bertram, H.C. NMR-Based Milk Metabolomics. Metabolites 2013, 3, 204-222. [CrossRef]

86. Wishart, D.S. Metabolomics: Applications to food science and nutrition research. Trends Food Sci. Technol. 2008, 19, 482-493. [CrossRef]

87. Foroutan, A.; Guo, A.C.; Vazquez-Fresno, R.; Lipfert, M.; Zhang, L.; Zheng, J.M.; Badran, H.; Budinski, Z.; Mandal, R.; Ametaj, B.N.; et al. Chemical Composition of Commercial Cow's Milk. J. Agric. Food Chem. 2019, 67, 4897-4914. [CrossRef]

88. Sen, C.; Ray, P.R.; Bhattacharyya, M. A critical review on metabolomic analysis of milk and milk products. Int. J. Dairy Technol. 2021, 74, 17-31. [CrossRef]

89. Marincola, F.C.; Dessi, A.; Corbu, S.; Reali, A.; Fanos, V. Clinical impact of human breast milk metabolomics. Clin. Chim. Acta 2015, 451, 103-106. [CrossRef]

90. Zhao, Y.R.; Chen, H.; Feng, J.H.; Chen, Z.W.; Cai, S.H. H-1 NMR-based compositional identification of different powdered infant formulas. Food Chem. 2017, 230, 164-173. [CrossRef]

91. Scano, P.; Murgia, A.; Demuru, M.; Consonni, R.; Caboni, P. Metabolite profiles of formula milk compared to breast milk. Food Res. Int. 2016, 87, 76-82. [CrossRef]

92. Garwolinska, D.; Hewelt-Belka, W.; Kot-Wasik, A.; Sundekilde, U.K. Nuclear Magnetic Resonance Metabolomics Reveals Qualitative and Quantitative Differences in the Composition of Human Breast Milk and Milk Formulas. Nutrients 2020, $12,921$. [CrossRef]

93. Thevenier, A.; Marchesini, G.; Schuh, S. WO/2018/115340—Infant Formula for Cow's Milk Protein Allergic Infants. Available online: https://patentimages.storage.googleapis.com/8b/c5/80/137f1654e0d057/WO2018115340A1.pdf (accessed on 5 April 2021).

94. El-Agamy, E.I.; Nawar, M.; Shamsia, S.M.; Awad, S.; Haenlein, G.F.W. Are camel milk proteins convenient to the nutrition of cow milk allergic children? Small Rumin. Res. 2009, 82, 1-6. [CrossRef]

95. Polidori, P.; Cammertoni, N.; Santini, G.; Klimanova, Y.; Zhang, J.-J.; Vincenzetti, S. Nutritional Properties of Camelids and Equids Fresh and Fermented Milk. Dairy 2021, 2, 288-302. [CrossRef] 